\title{
Review
}

Pharmacology

\section{Passive Immunization against Congenital Cytomegalovirus Infection: Current State of Knowledge}

\author{
Julia Jückstock ${ }^{a} \quad$ Markus Rothenburger ${ }^{b} \quad$ Klaus Friese $^{a} \quad$ Friederike Traunmüller $^{c}$ \\ ${ }^{a}$ Department of Gynecology and Obstetrics I, Ludwig-Maximilians-University, Munich, and ${ }^{\text {b }}$ Biotest AG, Dreieich,

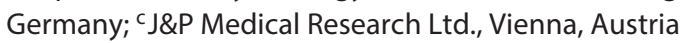

\section{Key Words}

Betaherpesvirus · Seroconversion · Immune globulin therapy · Fetal sonographic anomalies · Hearing deficit . Sensorineural sequelae

\begin{abstract}
Primary infection with the human cytomegalovirus (CMV) occurs in $1-4 \%$ of pregnancies. The rates of maternal-fetal CMV transmissions are around $25,36,41$, and $66 \%$, for infections occurring in the peri-conceptional weeks, first, second, and third trimester of pregnancy, respectively. On the other hand, the severity of fetal organ damage and dysfunction diminishes with increasing gestational age. Congenitally CMV-infected newborns may have neurosensory impairments like mental retardation, cerebral palsy, epilepsy, progressive hearing loss or visual defects, or even may have a fatal outcome. In in-vitro experiments, CMV specific neutralizing IgG antibodies - which are abundant in CMV specific hyperimmune globulin (HIG) products - inhibited the entry of the virus into target cells and hampered viral cell-to-cell spread. This article provides a brief overview on the epidemiology and diagnostic tools in congenital CMV infection. It also concisely summarizes the currently available study results on the safety and effectiveness of HIG treatment. Accordingly, in clinical studies HIG administration to expectant mothers following primary CMV infection (prophylactic use) was shown to lower the risk of maternal-fetal transmission of CMV compared to untreated controls. HIG was also able to
\end{abstract}

(c) 2015 S. Karger AG, Base

0031-7012/15/0956-0209\$39.50/0 ameliorate the disease sequelae in evidently infected fetuses (therapeutic use), as demonstrated by the regression or even resolution of sonographic pathologies including placental inflammation.

(c) 2015 S. Karger AG, Basel

\section{Epidemiology of Cytomegalovirus Infection in Pregnancy and Preventive Measures}

Human cytomegalovirus (CMV) is a double-stranded, enveloped DNA virus belonging to the betaherpesvirus subfamily. After coming into contact with CMV containing body fluids such as blood, saliva, urine, breast milk or genital secretions, the virus invades mucosal surfaces and replicates in permissive cells (myeloic cells, hepatocytes, lung fibroblasts, endothelia, cytotrophoblast, neuronal precursor cells, etc.) [1-5]. After repeated waves of viremia, the virus establishes lifelong latency in myeloic cells $[1,2]$. However, reactivation of latent CMV or reinfection with a different CMV strain, accompanied by periodic episodes of viral shedding via bodily fluids, can occur in seropositive individuals [2]. While primary CMV infection in immunocompetent individuals is mostly asymptomatic or manifests itself as a mild flu-like syndrome, CMV infection in immunocompromised subjects or fetuses results in a serious, sometimes even life-threatening complication [6].

Depending on the population (industrialized vs. developing regions) and social status, around $10-50 \%$ of

\section{KARGER 125}

E-Mail karger@karger.com

www.karger.com/pha
Friederike Traunmüller, MD

J\&P Medical Research Ltd.

Mooslackengasse 17

AT-1190 Vienna (Austria)

E-Mail friederike.traunmueller@jp-medical-research.com 
women at childbearing age are seronegative for CMV, and $1-4 \%$ of them contract primary infection during pregnancy. Vertical transmission rates of $30-50 \%$ were reported [7-12].

The global prevalence of congenital CMV infection in newborns is $0.64 \%$ [9]. At birth, approximately 10 $25 \%$ of congenitally CMV-infected newborns present with clinical signs such as jaundice, petechiae, hepatosplenomegaly, microcephaly, and cerebral cortical malformations [8]. In general, symptomatic newborns have an unfavorable prognosis: approximately, $5-15 \%$ die within the first 6 weeks of life, and 40-60\% typically suffer from mental retardation, cerebral palsy, epilepsy, progressive hearing loss or visual defects, resulting in permanent disabilities $[6,8,13,14]$. As miscarriages are seldom recognized as a consequence of primary CMV infection, the true number of affected infants is estimated to be even higher than what reports from literature suggest. However, also $10-15 \%$ of infants asymptomatic at birth may develop long-term sequelae later in life $[8,15]$. In fact, more children suffer from permanent disabilities due to congenital CMV infection than due to diseases of higher public awareness such as Down syndrome, fetal alcohol syndrome, or neural tube defects [15].

Hygienic measures constitute an effective way to lower the rate of primary CMV infection in pregnant women [16-18]. As latently infected young infants may shed $\mathrm{CMV}$ in urine or saliva over years, they represent the most common source of expectant mothers' infection [2, 19]. Therefore, the Center for Disease Control and Prevention (CDC) recommends to seronegative pregnant women very simple and manageable hygienic precaution measures like frequent hand washing after contact with body fluids of a child who's CMV status is positive or unknown, and avoidance of too intimate contact with such a child (i.e. kisses on the mouth, sharing food, drink or flatware), to reduce their risk of infection. However, according to surveys conducted in the United States between 2005 and 2007, only $14-22 \%$ of female respondents out of the general population ever had heard of CMV $[20,21]$, and only about a half of obstetricians and gynecologists routinely counseled their patients about CMV and infection-prevention measures [20,22].

\section{Pathophysiology of Intrauterine CMV Infection}

CMV replicates in uterine glandular epithelium and capillary endothelial cells and spreads to cytotrophoblasts and vasculature in the villous core [23-25]. Recent obser- vations suggest that the virus utilizes the fetal Fc-receptor for its transfer across the decidual-placental interface. The physiological role of the neonatal Fc-receptor is to actively transport IgG from the intervillous space (maternal blood flow) to the syncytiotrophoblast $[26,27]$. Both, the expression of this receptor and the IgG transfer increase with gestational age $[27,28]$. This might explain why vertical transmission rates, as well as potentially protective maternal IgG antibodies in the fetal bloodstream are higher in the late gestation as compared to the first or second trimester $[29,30]$. Indeed, the transmission rates among studies are remarkably consistent ranging from $30-42 \%, 38-44 \%$, and $59-73 \%$ for the first, second, and third trimester, respectively [10, 12, 30, 31]. For infections in the pre-conceptional (3-12 weeks before conception) and peri-conceptional (less than 3 weeks before conception to the time after conception) period, the risk of CMV transmission is approximately $6-9 \%$ and $19-31 \%$, respectively [30, 32-34]. Infections during early pregnancy bear the highest risk of severe sequelae in the offspring $[12,33,35,36]$. The clinical signs observed in CMV infected fetuses and newborns are likely to be associated with the cytopathic effects of the virus, inflammatory reactions secondary to viral replication, or the consequences of placental dysfunction [37-40].

\section{Diagnosis of Primary Maternal and Fetal CMV Infection and Prognostic Factors}

Recent primary maternal CMV infection is diagnosed by the detection of CMV-specific IgM and low-avidity IgG in serum of a previously seronegative subject (seroconversion) $[41,42]$. A detectable antibody response usually appears at about $2-12$ weeks after virus contact [41, 43]. Sonographic signs such as an increase in placental vertical diameter, hyperechogenic bowel, hydronephrosis, fetal hydrops, hepatomegaly, cerebral periventricular echodensities, cerebral ventriculomegaly, microcephalus and overall growth retardation are typical and indicative signs of materno-fetal CMV transmission [38, 44, 45]. According to Guerra and colleagues, ultrasound examinations do have positive and negative predictive values of 78 and $48 \%$, respectively, for poor clinical outcome of evidently infected fetuses [44]. As the placenta is one of the fetal structures most heavily affected by intrauterine CMV infection [24], the increased placental thickness in primarily CMV-infected pregnant women has also been identified as a prognostic marker $(\mathrm{p}<0.0001)$. The placental thickening is even more pronounced when accom- 
panied by fetal anomalies $(\mathrm{p}<0.0001)$ and should, thus, be included in the overall estimate of fetal prognosis [38].

The detection of CMV-DNA via polymerase chain reaction (PCR) in amniotic fluid samples (>20th week of gestation and $>6$ weeks after presumed maternal infection) constitute proof of maternal-fetal virus transmission $[41,42]$. Contrary to what physicians might anticipate, the viral load in the amniotic sac does not seem to be a reliable predictor of neonatal clinical outcome [46, 47]. Furthermore, data on the usefulness of CMV specific IgM and CMV-DNA concentrations in fetal umbilical cord blood as prognostic parameters are conflicting $[41,48,49]$.

In the newborn, it is recommended to perform PCR for CMV-DNA in urine or saliva in the first two postnatal weeks. This approach helps to discriminate between congenital infection and perinatal infection (from cervical secretions, breast feeding or blood products) [41, 42]. Information from umbilical cord blood collected after delivery is regarded as less reliable, because blood may be heavily contaminated with maternal cells [50]. Less frequently or not routinely employed diagnostic methods include the detection of viral antigens (e.g. pp65) or virusspecific RNA in blood, rapid virus culture and immunohistochemistry [41].

The premature termination of pregnancy is still the 'only option' frequently offered to parents who are not willing to give birth to a severely disabled neonate in case of documented fetal CMV infection combined with sonographically confirmed anomalies in the fetus [41]. However, premature termination at this stage of pregnancy may be subject to legal restrictions and may give rise to ethical objections; this is because of the fact that the severity of the neonate's deficits is difficult to predict $[41,51$, 52]. Facing this social and ethical dilemma, health care professionals increasingly recognize anti-CMV specific hyperimmune globulin preparations (HIG) - though currently not approved for this indication - as a treatment option that is worth considering.

\section{Mechanism of Action of CMV-Specific Hyperimmune Globulin}

Circumstantial scientific evidence supports the concept of protecting fetuses from vertical CMV transmission and severe CMV-related sequelae by the administration of HIG. In detail, the maternal-fetal CMV transmission rate is considerably lower in pregnant women with preexisting humoral immunity (CMV reactivation or reinfection) than in women experiencing primary CMV infection (1.4 vs. 30-50\%), respectively [9]. Likewise, CMV-related sequelae in corresponding newborns are milder or even absent $[19,53]$, although hearing deficits were reported to occur at a similar rate [54]. Moreover, the plasma titers of CMV-specific neutralizing IgG with high avidity are inversely correlated with virus transmission rates and with CMV associated histopathological findings in placenta tissue $[25,26,42,55]$. The observation that neonatal clinical manifestations and sequelae of CMV infection run a much milder course, if the maternal infection occurs in the late second or third trimester of pregnancy (when the trans-placental antibody transfer is already well developed), fits the concept [27, 28, 31, 33, 35, 36].

The results of recent in-vitro experiments emphasize that the abrogation of virus infectivity by specific neutralizing IgG is accomplished through the process of binding to viral envelope glycoproteins that is crucial for entry into the target cells $[56,57]$. Commercially available immune globulin formulations manufactured from plasma of selected donors with high anti-CMV antibody titers (anti-CMV hyperimmune globulin; HIG) have a high neutralizing capacity [58]. In addition, HIG was reported to exert modulatory activities on the complement system, cytokine milieu, expression of Fc receptors, and lymphocyte activation [59-61]. These effects are thought to mitigate inflammatory tissue damage in response to the replication of CMV in fetal organs, as suggested by studies on murine brains and human placental tissue [40,62].

In human clinical studies, HIG treatment was evaluated either for its effectiveness in the prophylaxis of maternal-fetal transmission of CMV or for its therapeutic effect on the severity of manifestations and complications in already infected fetuses.

\section{HIG for the Prophylaxis of Maternal-Fetal CMV Transmission}

In table 1, all studies currently available in literature on the prophylactic action of HIG in women primarily infected with CMV during pregnancy are summarized. Based on the half-life of IgG of about 22 days [63], HIG was offered as monthly infusions of 100-200 Paul Ehrlich Institute Units (PEIU; units based on the reference standard of the German Federal Institute for Vaccines and Biomedicines) per kilogram maternal body weight $[46,64$, 65]. In one prospective study [46], this treatment reduced the rate of fetal CMV infection from 40 to $16 \%$ as compared to a control group receiving standard prenatal care $(\mathrm{p}=0.02$; table 1$)$. Buxmann and coworkers [64] published 
Table 1. Clinical studies having investigated the effect of HIG treatment for the prophylaxis of vertical CMV transmission

\begin{tabular}{|c|c|c|c|c|c|c|c|}
\hline $\begin{array}{l}\text { Author, year } \\
\text { [Ref.] }\end{array}$ & Design & $\mathrm{n}$ & $\begin{array}{l}\text { Dosing regimen } \\
(\mathrm{PEIU} / \mathrm{kg} / \text { dose })^{\mathrm{a}}\end{array}$ & $\begin{array}{l}\text { Newborn } \\
\text { follow-up } \\
\text { (years) }\end{array}$ & Outcome parameter & \multicolumn{2}{|l|}{ Results } \\
\hline $\begin{array}{l}\text { Buxmann et al., } \\
2012[64]\end{array}$ & Retrosp. & 38 & $\begin{array}{l}100-200^{c} \\
1-3 \text { doses }\end{array}$ & $1-3$ & $\begin{array}{l}\text { Percentage of congenitally } \\
\text { infected neonates/fetuses }\end{array}$ & $\begin{array}{l}9 / 38^{\mathrm{d}}(24 \%) \\
0 \text { symptomatic, } 1 \\
\text { induced abortion }\end{array}$ & - \\
\hline $\begin{array}{l}\text { Revello et al., } \\
2014 \text { [65] }\end{array}$ & $\begin{array}{l}\text { Prosp., } \\
\mathrm{rd}, \mathrm{db}\end{array}$ & 123 & $\begin{array}{l}100 \mathrm{q} 4 \mathrm{w} \\
3-6 \text { doses }\end{array}$ & 0 & $\begin{array}{l}\text { Percentage of congenitally } \\
\text { infected neonates/fetuses }\end{array}$ & $\begin{array}{l}18 / 61(30 \%), p=0.13 \\
3 / 10 \text { symptomatic } \\
(8 \text { abortions })^{\mathrm{e}}\end{array}$ & $\begin{array}{l}27 / 62(44 \%) \\
4 / 17 \text { symptomatic } \\
(10 \text { abortions })^{e}\end{array}$ \\
\hline
\end{tabular}

$\mathrm{n}=$ Number of pregnant women with primary CMV infection included; prosp. = prospective; retrosp. = retrospective; $\mathrm{nrd}=$ non-randomized; $\mathrm{rd}=$ randomized; $\mathrm{db}=$ double-blinded; $\mathrm{qX} \mathrm{w}=$ every $\mathrm{X}$ weeks. In all studies, a $\mathrm{p}$ value $<0.05$ versus controls was considered statistically significant. ${ }^{\text {a }}$ Paul Ehrlich Institute Units (units based on the reference standard of the German Federal Institute for Vaccines and Biomedicines). The dose per kg maternal bodyweight was given intravenously to the expectant mothers. b The term 'symptomatic' refers to CMV-related signs and symptoms at the end of the follow-up period. ${ }^{c}$ Dosing interval not given. ${ }^{\mathrm{d}}$ Number of newborns of mothers solely treated by intravenous infusion. ${ }^{\mathrm{e}} \mathrm{A}$ total of 17 induced abortions and 1 spontaneous miscarriage in the control group (all not examined for CMV infection). retrospectively collected data on prophylactic HIG treatment and found the overall proportion of congenitally infected newborns to be $24 \%$, which was lower than what authors had expected from their standard of care collective. Only 2/15 (13\%) and 4/14 (29\%) women diagnosed with primary CMV infection in the first and second trimester, respectively, gave birth to infected newborns, compared to the transmission rates of $30-42 \%$ and 38 $44 \%$, respectively, in literature $[10,12,30,31]$. The rate of $22 \%(2 / 9)$ of infected newborns born by mothers after periconceptional CMV infection was in line with the rate of $19-31 \%$ previously reported for this subset $[32,33]$. However, a historical control group from the same study center was not included in this analysis. Another investigation, designed as a randomized, placebo-controlled, double-blinded study [65] comparing monthly infusions of HIG versus placebo was recently published and showed a trend in favor of prophylactic HIG treatment. The difference between groups, however, did not reach statistical significance ( 30 vs. $44 \% ; \mathrm{p}=0.13$; table 1 ). Interestingly, none of the 10 infected newborns from HIG-treated mothers, but 3 out of the overall 68 uninfected newborns presented with hearing deficits. It is worth mentioning that in two prophylaxis studies [46, 64], all of the congenitally infected children born alive by HIG-treated mothers were asymptomatic at birth and at follow-up (table 1).

However, these clinical studies did not provide information on the CMV infection status of the fetus prior to the start of HIG administration, and thus HIG treatment might have been therapeutic rather than prophylactic in distinct cases. Furthermore, the mild and unspecific clinical symptoms of maternal CMV infection, and the large variability in the diagnostic window of CMV infection detection, make the definition of the appropriate time point for the start of prophylactic HIG treatment very difficult.

\section{Therapeutic Effectiveness of HIG in Congenitally Infected Fetuses}

\section{Clinical Outcome of Congenitally Infected Newborns}

Since 1999, several case reports have provided circumstantial evidence that timely HIG administration to expectant mothers and/or their fetuses is able to reduce the severity of evidently CMV-associated fetal anomalies [66-69]. Larger case series and clinical trials studying this potential therapeutic effect included 12-68 mothers diagnosed with fetal CMV infection (table 2). In brief, among four prospective, controlled studies, one study showed a significantly lower rate of newborns with congenital CMV infections being symptomatic at birth ( $3 \mathrm{vs.50 \% ).} \mathrm{Three} \mathrm{studies} \mathrm{found}$ a significantly lower rate of $\mathrm{CMV}$-infected infants presenting with sequelae after treatment with HIG as compared to standard-of-care control groups (11-13\% vs. $43-100 \%)$ $[46,70,71]$. In a retrospective, matched case-control study 
Table 2. Clinical studies having investigated the therapeutic effect of HIG on CMV-related fetal anomalies and clinical outcome of evidently infected newborns

\begin{tabular}{|c|c|c|c|c|c|c|c|}
\hline $\begin{array}{l}\text { Author, } \\
\text { year [Ref.] }\end{array}$ & Design & $\mathrm{n}$ & $\begin{array}{l}\text { Dosing regimen } \\
(\mathrm{PEIU} / \mathrm{kg} / \text { dose })^{\mathrm{a}}\end{array}$ & $\begin{array}{l}\text { Newborn } \\
\text { follow-up } \\
\text { (years) }\end{array}$ & Outcome parameter & \multicolumn{2}{|l|}{ Results } \\
\hline $\begin{array}{l}\text { Nigro et al., } \\
2005 \text { [46] }\end{array}$ & Prosp., nrd & 45 & $\begin{array}{l}200 \text { q2-6w (plus } \\
400 \text { i.a. or i.u. in } 9 \\
\text { subjects) } 1-3 \text { doses }\end{array}$ & 2 & $\begin{array}{l}\text { Resolution or regress of fetal } \\
\text { sonographic anomalies incl. IUGR } \\
\text { Percentage of symptomatic newborns }\end{array}$ & $\begin{array}{l}14 / 15(93 \%) \\
1 / 31(3 \%)^{b} \\
p<0.001\end{array}$ & $\begin{array}{l}0 / 7 \\
7 / 14(50 \%)\end{array}$ \\
\hline $\begin{array}{l}\text { Nigro et al., } \\
2012 \text { [72] }\end{array}$ & $\begin{array}{l}\text { Retrosp., } \\
\text { case-control }\end{array}$ & 64 & $\begin{array}{l}200 q 2-4 w \\
1-4 \text { doses }\end{array}$ & $1-5$ & $\begin{array}{l}\text { Resolution or regress of fetal } \\
\text { sonographic anomalies incl. IUGR } \\
\text { Percentage of infants with } \\
\text { sequelae }\end{array}$ & $\begin{array}{l}9 / 14(64 \%) \\
4 / 31(13 \%) \\
p<0.001\end{array}$ & $\begin{array}{l}5 / 17(29 \%) \\
28 / 33(85 \%)\end{array}$ \\
\hline $\begin{array}{l}\text { Visentin et al., } \\
2012 \text { [71] }\end{array}$ & Prosp., nrd & 68 & $\begin{array}{l}200 \\
1 \text { dose }\end{array}$ & 1 & $\begin{array}{l}\text { Resolution or regress of fetal } \\
\text { sonographic/MRI anomalies incl. IUGR } \\
\text { Percentage of infants with sequelae }\end{array}$ & $\begin{array}{l}0 / 4 \\
4 / 31(13 \%) \\
p<0.01\end{array}$ & $\begin{array}{l}0 / 5 \\
16 / 37(43 \%)\end{array}$ \\
\hline $\begin{array}{l}\text { JCCIIFTSG } \\
2012[73]\end{array}$ & $\begin{array}{l}\text { Prosp., } \\
\text { uncontrolled }\end{array}$ & 12 & $\begin{array}{l}\sim 100-200^{\mathrm{g}} \mathrm{q} 1 \mathrm{w} \\
1-5 \text { doses and/or } \\
\sim 500-1,800^{\mathrm{e}, \mathrm{g}} \mathrm{q} 1 \mathrm{w} \\
2-6 \text { doses i.p. }\end{array}$ & $2-6$ & $\begin{array}{l}\text { Resolution or regress of fetal } \\
\text { sonographic anomalies incl. IUGR } \\
\text { Percentage of infants with } \\
\text { sequelae }\end{array}$ & $\begin{array}{l}9 / 12^{\mathrm{h}}(75 \%) \\
9 / 12^{\mathrm{h}}(75 \%) \\
\text { incl. } 2 \text { neonatal } \\
\text { deaths }\end{array}$ & - \\
\hline
\end{tabular}

$\mathrm{n}=$ Number of pregnant women with primary CMV infection included; JCCIIFTSG = Japanese Congenital Cytomegalovirus Infection Immunoglobulin Fetal Therapy Study Group; prosp. = prospective; retrosp. = retrospective; $\mathrm{nrd}=$ non-randomized; $\mathrm{qXw}=$ every $\mathrm{X}$ weeks; i.p. = intraperitoneally (fetal abdominal cavity); i.a. = intraamniotically; i.u. = intraumbilically (via cordocentesis); MRI = magnetic resonance imaging; IUGR = intrauterine growth retardation. In all studies, a $\mathrm{p}$ value $<0.05$ versus controls was considered statistically significant. ${ }^{\text {a }}$ Paul Ehrlich Institute Units (units based on the reference standard of the German Federal Institute for Vaccines and Biomedicines). If not otherwise specified, the dose per kg maternal bodyweight was given intravenously to the expectant mothers; for occasional fetal treatment, dose per fetal bodyweight is indicated. b $8 / 9$ fetuses having been treated via amniocentesis or cordocentesis were asymptomatic at birth and follow-up. ${ }^{\mathrm{c}}$ Dosing interval not giv- en. ${ }^{d}$ This study included a fourth women treated solely via amniocentesis and cordocentesis who gave birth to a symptomatic newborn. ${ }^{\mathrm{e}} \mathrm{A}$ fetal weight of $0.5 \mathrm{~kg}$ was assumed to convert the absolute dose. ${ }^{\mathrm{f}}$ The sample included 3 pregnant women with secondary CMV infection ( 1 in the treatment group - normal outcome of the infant, 2 in the control group - both infants symptomatic) and 2 women with twin pregnancies. ${ }^{\mathrm{g}} \mathrm{A}$ HIG titer of 1 PEIU per mg product and a maternal body weight of $75 \mathrm{~kg}$ was assumed to convert the absolute dose. ${ }^{\mathrm{h}}$ Sole maternal treatment in 1 subject (newborn with unilateral hearing deficit), sole fetal treatment in 7 subjects ( 1 newborn with normal outcome, 5 newborns with sequelae, 1 symptomatic newborn died from respiratory failure), combined treatment of mother and fetus in 4 mother-fetus pairs (2 newborns normal, 1 symptomatic newborn died from respiratory failure, 1 newborn with unilateral hearing deficit and mild development delay). by Nigro et al. [72], the absence of HIG treatment was the only independent predictor for complete or partial hearing loss (adjusted odds ratio 10 (95\% CI 1.3, 84)). In an uncontrolled study performed by a Japanese research group [73], the therapeutic effect of HIG treatment was less convincing. In this study, $3 / 12(25 \%)$ of children at $>2$ years of age had a normal outcome, whereas $9 / 12(75 \%)$ presented with hearing impairment or with development delay (7 newborns), or died from respiratory failure within the first month of life (2 newborns). It is worth noting that in this study, 7/12 of mothers received HIG treatment exclusively into the fetal abdominal cavity, which resulted in a rate of 
$6 / 7$ of newborns presenting with unfavorable or fatal outcome. Thus, although this route of HIG administration was previously shown to increase the level of IgG in the fetal plasma compartment [74], the risk to benefit assessment of this approach remains to be readdressed [75].

\section{Regress of Fetal CMV-Related Anomalies}

Pathologies typical for CMV infection improved considerably or even resolved completely following intravenous HIG treatment of pregnant women, whether or not combined with intraperitoneal or intraumbilical treatment of fetuses, as demonstrated by serial ultrasonographic examinations. Fetal growth retardation and/or sonographic anomalies frequently observed during CMV infection regressed or resolved in a total of 39/54 (72\%) of fetuses in HIG groups, while such observation was rarely made in untreated mother-fetus pairs (8/37 [22\%]) (table 2). However, the study by Visentin et al. [71] indicated that a single dose of HIG may not be sufficient in this indication (table 2). As CMV-related placental dysfunction was suggested to play an important role in the development of central nervous malformations typically found in fetal CMV disease [37-40], La Torre et al. and others speculated that the regress of placentitis following HIG treatment $[24,38]$ is paralleled by an amelioration of neurologic disease manifestations in the newborn $[24,38,40]$. The overall high rates of symptomatically infected newborns in the trials presented in tables 1 and 2 may be due to the inclusion of mothers infected during the highly vulnerable phase in the first or second trimester of pregnancy $[12,33,35,36]$, with overrepresentation of infections in the first trimester (except for the Japanese study).

\section{Limitations of the Reviewed Studies}

Recruitment rates of women showing CMV seroconversion during pregnancy are relatively low in prospectively performed clinical studies (table 2). Furthermore, the direct comparison of the study results should be performed only with caution because HIG dosage, route of administration, duration of treatment and the time interval between assumed CMV infection and first HIG administration varied considerably among the studies and even among subjects within the same study (tables 1 and 2). Again, it is important to recall that to date, unspecific and low-symptomatic clinical manifestations of infections - such as observed during CMV infection - do not allow for the determination of the true onset of the infection with satisfying reliability [6]. However, the early detection of maternal CMV infection is crucial for taking effective prophylactic measures in order to avoid vertical
CMV transmission. The period of follow-up investigations of the newborn is also of relevance. Investigators scheduling neonatal follow-up periods shorter than two years might miss the identification of potential motoric abnormalities or cognitive impairments which might become obvious later in time $[8,14]$.

\section{Safety of HIG Administration}

Since the late 1980s, plasma donors are carefully selected from a large population of potential of volunteers. In addition, highly elaborate manufacturing processes have been established for plasma-derived pharmaceutical products, which practically exclude contamination with viruses or prions. Today, these processes include virus inactivation and removal steps such as cold-ethanol fractioning, solvent-detergent treatment, incubation at low $\mathrm{pH}$, pasteurization, and nanofiltration, all of which, taken separately, are demonstrably capable of reducing model viruses and prions by several orders of magnitude from baseline [76-78].

Mild and transient untoward effects associated with intravenous immune globulin treatment (e.g. low-grade fever, nausea, myalgia, flushing, chills, malaise, etc.) typically occur during the first infusion or 1 to 3 days later. Patients experiencing tension headaches during an IVIG infusion often have a history of hypertension. The development of a localized mild and transient urticarial reaction is also common. Serious complications like aseptic meningitis, renal failure, hemolysis, or thromboembolic complications are rare and were mainly observed in patients with predisposing underlying risk factors, after exceptionally high doses, or after administration of formulations containing tubulotoxic stabilizers (no longer in use) [79-81]. Anaphylactic reactions to intravenous immune globulins are extremely rare and often associated with preexisting autoantibodies (e.g. anti-IgA) [80, 82]. Therefore, intravenous HIG application to pregnant women is considered a very low-risk procedure. In contrast, injection into the amniotic sac, and even more the cannulation of the fetal abdominal cavity or the umbilical cord occasionally performed in studies (table 2) should be restricted to specialized centers $[41,75]$.

In a majority of study reports and publications, therapy with HIG is considered a safe and well-tolerated option. However, Revello and colleagues [65] paid particular attention on to six preterms and two growth-retarded uninfected newborns in the treatment group versus none in the placebo group. Contradictory results brought a re- 
cent retrospective analysis pooling the clinical data of 358 primarily infected women (164 received HIG). This study found that birth weight and gestational age of neonates at delivery were significantly higher following administration of monthly multiple doses of HIG to mothers compared to untreated controls $(\mathrm{p}<0.02)$ [83].

\section{Summary and Prospects}

Congenital CMV infection still constitutes one of the predominant causes of severe and permanent disabilities in children. Attempts to develop a reliable active CMV vaccine have not been successful so far [84]. Although the relevance of congenital CMV infection to public health is well known for more than 50 years [85], routine CMV serology screening programs in expectant mothers are not yet established in most countries [41]. This is because no CMV-specific treatment approved or established in pregnancy is currently available $[6,11,52]$. However, the studies reviewed in this article point to the assumption that HIG might be effective in the prophylaxis of maternal-fetal transmission of CMV, and might help reducing $\mathrm{CMV}$-associated pathologies in fetuses. Also, the widespread assessment of the CMV serology status of expectant mothers early after conception might add to disease prevention. In particular, it would (a) enable individualized hygiene counseling (primary prevention), (b) increase the understanding and awareness to flu-like symptoms in CMV-naïve expectant mothers, and (c) increase the knowledge on potential interventions by use of HIG for prophylactic or therapeutic purposes [52]. The development of a fast, point-of-care CMV testing method with high sensitivity, specificity and reproducibility would constitute a tremendous step forward in this regard.

Currently available information on the effectiveness and safety of HIG therapy of CMV infections during pregnancy is very promising, but is based only on small clinical studies. More scientific evidence helping health care professionals to truly understand the value and clinical relevance of HIG administration for prophylactic and therapeutic reasons is expected to derive from the results of two currently unpublished, prospective, randomized clinical trials testing the safety and efficacy of the prophylactic treatment of CMV infection to expectant mothers (European Union Clinical Trials Registry No. 2007004692-19; U.S. National Institutes of Health registry for clinical trials, ID NCT01376778).

\section{Funding} AG.

This article was supported by an unrestricted grant from Biotest

\section{Disclosure Statement}

J.J. received research funding from Biotest AG. M.R. is Division Head of Medical and Regulatory Affairs at Biotest AG, the manufacturer of a CMV-specific HIG product which has been used in most studies reviewed in this article. F.T. is an employee of J\&P Medical Research Ltd., an independent life science research institute, which offers the entire spectrum of clinical research services. K.F. is principal investigator of a European-wide clinical trial evaluating the potential benefits of a CMV-specific hyperimmune globulin application in primarily CMV-infected pregnant women. For this trial he received research funding from Biotest AG.

\section{References}

1 Landolfo S, Gariglio M, Gribaudo G, Lembo D: The human cytomegalovirus. Pharmacol Ther 2003;98:269-297.

2 Britt W: Virus entry into host, establishment of infection, spread in host, mechanisms of tissue damage; in Arvin A, Campadelli-Fiume G, Mocarski E, Moore PS, Roizman B, Whitley R, Yamanishi K (eds): Human Herpesviruses: Biology, Therapy, and Immunoprophylaxis. Cambridge, Cambridge University Press, 2007, chapter 41.

3 Gerna G, Baldanti F, Revello MG: Pathogenesis of human cytomegalovirus infection and cellular targets. Hum Immunol 2004;65:381386.

Passive Immunization against Congenital CMV Infection
4 Fisher S, Genbacev O, Maidji E, Pereira L: Human cytomegalovirus infection of placental cytotrophoblasts in vitro and in utero: implications for transmission and pathogenesis. J Virol 2000;74:6808-6820.

5 Cheeran MC, Hu S, Ni HT, Sheng W, Palmquist JM, Peterson PK, Lokensgard JR: Neural precursor cell susceptibility to human cytomegalovirus diverges along glial or neuronal differentiation pathways. J Neurosci Res 2005;82:839-850

6 Jones CA: Congenital cytomegalovirus infection. Curr Probl Pediatr Adolesc Health Care 2003;33:70-93.

7 Cannon MJ: Congenital cytomegalovirus (CMV) epidemiology and awareness. J Clin Virol 2009;46(suppl 4):S6-S10.
8 Dollard SC, Grosse SD, Ross DS: New estimates of the prevalence of neurological and sensory sequelae and mortality associated with congenital cytomegalovirus infection. Rev Med Virol 2007;17:355-363.

9 Kenneson A, Cannon MJ: Review and metaanalysis of the epidemiology of congenital cytomegalovirus (CMV) infection. Rev Med Virol 2007; 17:253-276.

10 Bodéus M, Kabamba-Mukadi B, Zech F, Hubinont C, Bernard P, Goubau P: Human cytomegalovirus in utero transmission: follow-up of 524 maternal seroconversions. J Clin Virol 2010;47:201-202.

11 Adler SP: Screening for cytomegalovirus during pregnancy. Infect Dis Obstet Gynecol 2011;2011:1-9. 
12 Enders G, Daiminger A, Bäder U, Exler S, Enders $\mathrm{M}$ : Intrauterine transmission and clinical outcome of 248 pregnancies with primary cytomegalovirus infection in relation to gestational age. J Clin Virol 2011;52:244246.

13 Boppana SB, Pass RF, Britt WJ, Stagno S, Alford CA: Symptomatic congenital cytomegalovirus infection: neonatal morbidity and mortality. Pediatr Infect Dis J 1992;11: 93-99.

14 Fowler KB, Dahle AJ, Boppana SB, Pass RF: Newborn hearing screening: will children with hearing loss caused by congenital cytomegalovirus infection be missed? J Pediatr 1999;135:60-64.

15 Cannon MJ, Davis KF: Washing our hands of the congenital cytomegalovirus disease epidemic. BMC Public Health 2005;5:70.

16 Adler SP, Finney JW, Manganello AM, Best AM: Prevention of child-to-mother transmission of cytomegalovirus among pregnant women. J Pediatr 2004;145:485-491.

17 Harvey J, Dennis CL: Hygiene interventions for prevention of cytomegalovirus infection among childbearing women: systematic review. J Adv Nurs 2008;63:440-450.

18 Vauloup-Fellous C, Picone O, Cordier AG, Parent-du-Châtelet I, Senat MV, Frydman R, Grangeot-Keros L: Does hygiene counseling have an impact on the rate of CMV primary infection during pregnancy? Results of a 3 -year prospective study in a French hospital. J Clin Virol 2009;46(suppl 4):S49-S53.

19 Manicklal S, Emery VC, Lazzarotto T, Boppana SB, Gupta RK: The 'silent' global burden of congenital cytomegalovirus. Clin Microbiol Rev 2013;26:86-102.

20 Jeon J, Victor M, Adler SP, Arwady A, Demmler G, Fowler K, Goldfarb J, Keyserling H, Massoudi M, Richards K, Staras SA, Cannon MJ: Knowledge and awareness of congenital cytomegalovirus among women. Infect Dis Obstet Gynecol 2006;2006:80383.

21 Ross DS, Victor M, Sumartojo E, Cannon MJ: Women's knowledge of congenital cytomegalovirus: results from the 2005 HealthStyles survey. J Womens Health (Larchmt) 2008;17: 849-858.

22 Centers for Disease Control and Prevention (CDC): Knowledge and practices of obstetricians and gynecologists regarding cytomegalovirus infection during pregnancy - United States, 2007. MMWR Morb Mortal Wkly Rep 2008;57:65-68.

23 Maidji E, Percivalle E, Gerna G, Fisher S, Pereira L: Transmission of human cytomegalovirus from infected uterine microvascular endothelial cells to differentiating/invasive placental cytotrophoblasts. Virology 2002; 304:53-69.

24 Maidji E, Nigro G, Tabata T, McDonagh S, Nozawa N, Shiboski S, Muci S, Anceschi MM, Aziz N, Adler SP, Pereira L: Antibody treatment promotes compensation for human cytomegalovirus-induced pathogenesis and a hypoxia-like condition in placentas with con- genital infection. Am J Pathol 2010;177:12981310.

25 Pereira L, Maidji E, McDonagh S, Genbacev O, Fisher S: Human cytomegalovirus transmission from the uterus to the placenta correlates with the presence of pathogenic bacteria and maternal immunity. J Virol 2003;77: 13301-13314.

26 Maidji E, McDonagh S, Genbacev O, Tabata $T$, Pereira L: Maternal antibodies enhance or prevent cytomegalovirus infection in the placenta by neonatal $\mathrm{Fc}$ receptor-mediated transcytosis. Am J Pathol 2006;168:1210-1226.

27 Simister NE: Placental transport of immunoglobulin G. Vaccine 2003;21:3365-3369.

28 Mussi-Pinhata MM, Pinto PC, Yamamoto AY, Berencsi K, de Souza CB, Andrea M, Duarte G, Jorge SM: Placental transfer of naturally acquired, maternal cytomegalovirus antibodies in term and preterm neonates. J Med Virol 2003;69:232-239.

29 Malek A, Sager R, Kuhn P, Nicolaides KH, Schneider H: Evolution of maternofetal transport of immunoglobulins during human pregnancy. Am J Reprod Immunol 1996;36: 248-255.

30 Revello MG, Fabbri E, Furione M, Zavattoni M, Lilleri D, Tassis B, Quarenghi A, Cena C, Arossa A, Montanari L, Rognoni V, Spinillo A, Gerna G: Role of prenatal diagnosis and counseling in the management of 735 pregnancies complicated by primary human cytomegalovirus infection: a 20-year experience. J Clin Virol 2011;50:303-307.

31 Feldman B, Yinon Y, Tepperberg Oikawa M, Yoeli R, Schiff E, Lipitz S: Pregestational, periconceptional, and gestational primary maternal cytomegalovirus infection: prenatal diagnosis in 508 pregnancies. Am J Obstet Gynecol 2011;205:342.e1-e6.

32 Revello MG, Zavattoni M, Furione M, Lilleri D, Gorini G, Gerna G: Diagnosis and outcome of preconceptional and periconceptional primary human cytomegalovirus infections. J Infect Dis 2002;186:553-557.

33 Picone O, Vauloup-Fellous C, Cordier AG, Guitton S, Senat MV, Fuchs F, Ayoubi JM, Grangeot Keros L, Benachi A: A series of 238 cytomegalovirus primary infections during pregnancy: description and outcome. Prenat Diagn 2013;33:751-758.

34 Revello MG, Zavattoni M, Furione M, Fabbri E, Gerna G: Preconceptional primary human cytomegalovirus infection and risk of congenital infection. J Infect Dis 2006;193:783787.

35 Ahlfors K, Forsgren M, Ivarsson SA, Harris S, Svanberg L: Congenital cytomegalovirus infection: on the relation between type and time of maternal infection and infant's symptoms. Scand J Infect Dis 1983;15:129-138.

36 Lipitz S, Yinon Y, Malinger G, Yagel S, Levit L, Hoffman C, Rantzer R, Weisz B: Risk of cytomegalovirus-associated sequelae in relation to time of infection and findings on prenatal imaging. Ultrasound Obstet Gynecol 2013;41:508-514.
37 Mostoufi-Zadeh M, Driscoll SG, Biano SA, Kundsin RB: Placental evidence of cytomegalovirus infection of the fetus and neonate. Arch Pathol Lab Med 1984;108:403406.

38 La Torre R, Nigro G, Mazzocco M, Best AM, Adler SP: Placental enlargement in women with primary maternal cytomegalovirus infection is associated with fetal and neonatal disease. Clin Infect Dis 2006;43:994-1000.

39 Adler SP, Nigro G, Pereira L: Recent advances in the prevention and treatment of congenital cytomegalovirus infections. Semin Perinatol 2007;31:10-18

40 Gabrielli L, Bonasoni MP, Lazzarotto T, Lega S, Santini D, Foschini MP, Guerra B, Baccolini F, Piccirilli G, Chiereghin A, Petrisli E, Gardini G, Lanari M, Landini MP: Histological findings in foetuses congenitally infected by cytomegalovirus. J Clin Virol 2009;46(suppl 4):S16-S21.

41 Revello MG, Gerna G: Diagnosis and management of human cytomegalovirus infection in the mother, fetus and newborn infant. Clin Microbiol Rev 2002;15:680-715.

42 Lazzarotto T, Guerra B, Gabrielli L, Lanari M, Landini MP: Update on the prevention, diagnosis and management of cytomegalovirus infection during pregnancy. Clin Microbiol Infect 2011;17:1285-1293.

43 Pass RF, Griffiths PD, August AM: Antibody response to cytomegalovirus after renal transplantation: comparison of patients with primary and recurrent infections. J Infect Dis 1983;147:40-46.

44 Guerra B, Simonazzi G, Puccetti C, Lanari M, Farina A, Lazzarotto T, Rizzo N: Ultrasound prediction of symptomatic congenital cytomegalovirus infection. Am J Obstet Gynecol 2008;198:380.e1-e7.

45 Benoist G, Salomon LJ, Mohlo M, Suarez B, Jacquemard F, Ville Y: Cytomegalovirus-related fetal brain lesions: comparison between targeted ultrasound examination and magnetic resonance imaging. Ultrasound Obstet Gynecol 2008;32:900-905.

46 Nigro G, Adler SP, La Torre R, Best AM; Congenital Cytomegalovirus Collaborating Group: Passive immunization during pregnancy for congenital cytomegalovirus infection. N Engl J Med 2005;353:1350-1362.

47 Goegebuer T, Van Meensel B, Beuselinck K, Cossey V, Van Ranst M, Hanssens M, Lagrou K: Clinical predictive value of real-time PCR quantification of human cytomegalovirus DNA in amniotic fluid samples. J Clin Microbiol 2009;47:660-665.

48 Fabbri E, Revello MG, Furione M, Zavattoni M, Lilleri D, Tassis B, Quarenghi A, Rustico M, Nicolini U, Ferrazzi E, Gerna G: Prognostic markers of symptomatic congenital human cytomegalovirus infection in fetal blood. BJOG 2011;118:448-456.

49 Romanelli RM, Magny JF, Jacquemard F: Prognostic markers of symptomatic congenital cytomegalovirus infection. Braz J Infect Dis 2008; 12:38-43. 
50 Hall JM, Lingenfelter P, Adams SL, Lasser D, Hansen JA, Bean MA: Detection of maternal cells in human umbilical cord blood using fluorescence in situ hybridization. Blood 1995; 86:2829-2832.

51 Adler SP: Editorial commentary: Primary maternal cytomegalovirus infection during pregnancy: do we have a treatment option? Clin Infect Dis 2012;55:504-506.

52 Walker SP, Palma-Dias R, Wood EM, Shekleton P, Giles ML: Cytomegalovirus in pregnancy: to screen or not to screen. BMC Pregnancy Childbirth 2013;13:96.

53 Fowler KB, Stagno S, Pass RF, Britt WJ, Boll TJ, Alford CA: The outcome of congenital cytomegalovirus infection in relation to maternal antibody status. N Engl J Med 1992;326: 663-667.

54 Ross SA, Fowler KB, Ashrith G, Stagno S, Britt WJ, Pass RF, Boppana SB: Hearing loss in children with congenital cytomegalovirus infection born to mothers with preexisting immunity. J Pediatr 2006;148:332-336.

55 Boppana SB, Britt WJ: Antiviral antibody responses and intrauterine transmission after primary maternal cytomegalovirus infection. J Infect Dis 1995;171:1115-1121.

56 Freed DC, Tang Q, Tang A, Li F, He X, Huang Z, Meng W, Xia L, Finnefrock AC, Durr E, Espeseth AS, Casimiro DR, Zhang N, Shiver JW, Wang D, An Z, Fu TM: Pentameric complex of viral glycoprotein $\mathrm{H}$ is the primary target for potent neutralization by a human cytomegalovirus vaccine. Proc Natl Acad Sci U S A 2013;110:E4997-E5005.

57 Fouts AE, Comps-Agrar L, Stengel KF, Ellerman D, Schoeffler AJ, Warming S, Eaton DL, Feierbach B: Mechanism for neutralizing activity by the anti-CMV gH/gL monoclonal antibody MSL-109. Proc Natl Acad Sci U S A 2014;111:8209-8214.

58 Cui X, Meza BP, Adler SP, McVoy MA: Cytomegalovirus vaccines fail to induce epithelial entry neutralizing antibodies comparable to natural infection. Vaccine 2008;26:5760-5766.

59 Kazatchkine MD, Kaveri SV: Immunomodulation of autoimmune and inflammatory diseases with intravenous immune globulin. $\mathrm{N}$ Engl J Med 2001;345:747-755.

60 Hoetzenecker K, Hacker S, Hoetzenecker W, Sadeghi K, Sachet M, Pollreisz A, Mangold A, Wliszczak T, Bielek E, Muehlbacher F, Klepetko W, Ankersmit HJ: Cytomegalovirus hyperimmunoglobulin: mechanisms in allo-immune response in vitro. Eur J Clin Invest 2007;37:978-986

61 Novaretti MC, Dinardo CL: Immunoglobulin: production, mechanisms of action and formulations. Rev Bras Hematol Hemoter 2011;33:377-382.

62 Cekinović D, Golemac M, Pugel EP, Tomac J, Cicin-Sain L, Slavuljica I, Bradford R,
Misch S, Winkler TH, Mach M, Britt WJ, Jonjić S: Passive immunization reduces murine cytomegalovirus-induced brain pathology in newborn mice. J Virol 2008;82:1217212180.

63 Thürmann PA, Sonnenburg-Chatzopoulos C, Lissner R: Pharmacokinetic characteristics and tolerability of a novel intravenous immunoglobulin preparation. Eur J Clin Pharmacol 1995;49:237-242.

64 Buxmann H, Stackelberg OM, Schlößer RL, Enders G, Gonser M, Meyer-Wittkopf M, Hamprecht K, Enders M: Use of cytomegalovirus hyperimmunoglobulin for prevention of congenital cytomegalovirus disease: a retrospective analysis. J Perinat Med 2012;40: 439-446.

65 Revello MG, Lazzarotto T, Guerra B, Spinillo A, Ferrazzi E, Kustermann A, Guaschino S, Vergani P, Todros T, Frusca T, Arossa A, Furione $\mathrm{M}$, Rognoni $\mathrm{V}$, Rizzo N, Gabrielli L, Klersy C, Gerna G; CHIP Study Group: A randomized trial of hyperimmune globulin to prevent congenital cytomegalovirus. $\mathrm{N}$ Engl J Med 2014;370:1316-1326.

66 Nigro G, La Torre R, Anceschi MM, Mazzocco M, Cosmi EV: Hyperimmunoglobulin therapy for a twin fetus with cytomegalovirus infection and growth restriction. Am J Obstet Gynecol 1999;180:1222-1226.

67 Moxley K, Knudtson EJ: Resolution of hydrops secondary to cytomegalovirus after maternal and fetal treatment with human cytomegalovirus hyperimmune globulin. Obstet Gynecol 2008;111:524-526.

68 Moise KJ, Wolfe H: Treatment of second trimester fetal cytomegalovirus infection with maternal hyperimmune globulin. Prenat Diagn 2008;28:264-265.

69 Nigro G, La Torre R, Pentimalli H, Taverna P, Lituania M, de Tejada BM, Adler SP: Regression of fetal cerebral abnormalities by primary cytomegalovirus infection following hyperimmunoglobulin therapy. Prenat Diagn 2008;28:512-517.

70 Nigro G, Adler SP, Gatta E, Mascaretti G, Megaloikonomou A, La Torre R, Necozione $S$ : Fetal hyperechogenic bowel may indicate congenital cytomegalovirus disease responsive to immunoglobulin therapy. J Matern Fetal Neonatal Med 2012;25:2202-2205.

71 Visentin S, Manara R, Milanese L, Da Roit A, Forner G, Salviato E, Citton V, Magno FM, Orzan E, Morando C, Cusinato R, Mengoli C, Palu G, Ermani M, Rinaldi R, Cosmi E, Gussetti N: Early primary cytomegalovirus infection in pregnancy: maternal hyperimmunoglobulin therapy improves outcomes among infants at 1 year of age. Clin Infect Dis 2012; 55:497-503

72 Nigro G, Adler SP, Parruti G, Anceschi MM, Coclite E, Pezone I, Di Renzo GC: Im- munoglobulin therapy of fetal cytomegalovirus infection occurring in the first half of pregnancy - a case-control study of the outcome in children. J Infect Dis 2012;205: 215-227.

73 Japanese Congenital Cytomegalovirus Infection Immunoglobulin Fetal Therapy Study Group: A trial of immunoglobulin fetal therapy for symptomatic congenital cytomegalovirus infection. J Reprod Immunol 2012;95: 73-79.

74 Yoshida M, Matsuda H, Hasegawa Y, Yoshinaga Y, Asai K, Kawashima A, Furuya K: Accumulation of fetal IgG in immunoglobulin injection into the fetal abdominal cavity is proven. Fetal Diagn Ther 2011;29:229-232.

75 Kim SR, Won HS, Lee PR, Kim A: Four-dimensional ultrasound guidance of prenatal invasive procedures. Ultrasound Obstet Gynecol 2005;26:663-665.

76 Buchacher A, Iberer G: Purification of intravenous immunoglobulin $\mathrm{G}$ from human plasma - aspects of yield and virus safety. Biotechnol J 2006;1:148-163.

77 Ballow M: Safety of IGIV therapy and infusion-related adverse events. Immunol Res 2007;38:122-132.

78 Foster PR, Welch AG, McLean C, Griffin BD, Hardy JC, Bartley A, MacDonald S, Bailey AC: Studies on the removal of abnormal prion protein by processes used in the manufacture of human plasma products. Vox Sang 2000; 78:86-95.

79 Carbone J: Adverse reactions and pathogen safety of intravenous immunoglobulin. Curr Drug Saf 2007;2:9-18.

80 Hamrock DJ: Adverse events associated with intravenous immunoglobulin therapy. Int Immunopharmacol 2006;6:535-542.

81 Orbach H, Katz U, Sherer Y, Shoenfeld Y: Intravenous immunoglobulin: adverse effects and safe administration. Clin Rev Allergy Immunol 2005;29:173-184.

82 Rachid R, Bonilla FA: The role of anti-IgA antibodies in causing adverse reactions to gamma globulin infusion in immunodeficient patients: a comprehensive review of the literature. J Allergy Clin Immunol 2012;129:628-634.

83 Nigro G, Capretti I, Manganello AM, Best AM, Adler SP: Primary maternal cytomegalovirus infections during pregnancy: association of CMV hyperimmune globulin with gestational age at birth and birth weight. J Matern Fetal Neonatal Med 2015;28:168171

84 Fu TM, An Z, Wang D: Progress on pursuit of human cytomegalovirus vaccines for prevention of congenital infection and disease. Vaccine 2014;32:2525-2533.

85 Stern H, Tucker SM: Cytomegalovirus infection in the newborn and in early childhood. Three atypical cases. Lancet 1965;2:1268-1271. 